\title{
DO HEALTH PROBLEMS REDUCE CONSUMPTION AT OLDER AGES?
}

\author{
Barbara A. Butrica, Richard W. Johnson, and Gordon B.T. Mermin* \\ CRR WP 2009-9 \\ Released: March 2009 \\ Draft Submitted: January 2009
}

\author{
Center for Retirement Research at Boston College \\ Hovey House \\ 140 Commonwealth Avenue \\ Chestnut Hill, MA 02467
}

Tel: 617-552-1762 Fax: 617-552-0191

\begin{abstract}
* Barbara A. Butrica is a senior research associate and Richard W. Johnson is a senior fellow, both at The Urban Institute. Gordon B.T. Mermin was a senior research associate at The Urban Institute when the project began. The research reported herein was supported by the Center for Retirement Research at Boston College pursuant to a grant from the U.S. Social Security Administration funded as part of the Retirement Research Consortium The findings and conclusions expressed are solely those of the authors and do not represent the views of SSA, any agency of the Federal Government, the RRC or Boston College or the Urban Institute, its trustees, or its sponsors. The authors would like to thank Paul Van de Water for helpful comments on an earlier draft.

(C) 2009, by Barbara A. Butrica, Richard W. Johnson and Gordon B.T. Mermin. All rights reserved. Short sections of text, not to exceed two paragraphs, may be quoted without explicit permission provided that full credit, including (C) notice, is given to the source.
\end{abstract}




\title{
About the Center for Retirement Research
}

The Center for Retirement Research at Boston College, part of a consortium that includes parallel centers at the University of Michigan and the National Bureau of Economic Research, was established in 1998 through a grant from the Social Security Administration. The Center's mission is to produce first-class research and forge a strong link between the academic community and decision makers in the public and private sectors around an issue of critical importance to the nation's future. To achieve this mission, the Center sponsors a wide variety of research projects, transmits new findings to a broad audience, trains new scholars, and broadens access to valuable data sources.

\author{
Center for Retirement Research at Boston College \\ Hovey House \\ 140 Commonwealth Avenue \\ Chestnut Hill, MA 02467 \\ phone: 617-552-1762 fax: 617-552-0191 \\ e-mail: crr@bc.edu \\ www.bc.edu/crr
}

Affiliated Institutions:

The Brookings Institution

Massachusetts Institute of Technology

Syracuse University

Urban Institute 


\begin{abstract}
High out-of-pocket health care costs may have serious repercussions for older people and their families. If their incomes are not sufficient to cover these expenses, older adults with health problems may have to deplete their savings, turn to family and friends for financial help, or forego necessary care. Or they may be forced to reduce their consumption of other goods and services to pay their medical bills. This paper uses data from the Health and Retirement Study (HRS) and the related Consumption and Activities Mail Survey (CAMS) to examine the impact of health problems at older ages on out-of-pocket health care spending and other types of expenditures. The analysis estimates fixed effects models of total out-of-pocket health care spending, out-of-pocket health care spending exclusive of premiums, total spending on all items except health care, and total spending on all items except health care and housing. The models are estimated separately for households ages 65 and older and those ages 51 to 64 .

The results show that medical conditions increase health spending, particularly for households ages 51 to 64 , but that health conditions do not generally reduce nonhealth spending. Medical conditions do, however, reduce nonhealth spending for low-income households ages 51 to 64 , suggesting that holes in the health safety net before the Medicare eligibility age force some low-income people to lower their living standards to cover medical expenses.
\end{abstract}




\section{Introduction}

The possibility of serious illness poses significant financial risks for older adults. Although virtually all Americans ages 65 and older are covered by Medicare, cost-sharing requirements and the exclusion of certain services often lead to large out-of-pocket medical expenses, especially for those who lack private supplemental insurance health benefits. Older adults under age 65, who are not eligible for Medicare unless they are disabled, may face more serious financial risks because there is no guarantee that they will have health insurance. In fact, 12 percent of Americans ages 55 to 64 were uninsured in 2004 (Johnson 2007).

High out-of-pocket health care costs may have important repercussions for older people and their families. If their incomes are not high enough to cover these expenses, older adults with health problems may have to deplete their savings, turn to family and friends for financial help, or forego necessary care. Or they may be forced to reduce their consumption of other goods and services to pay their medical bills.

Relatively little is known about how health problems affect economic well-being. Widespread anecdotal evidence suggests that some older Americans are forced to choose between buying medications and paying for rent or groceries. There are no careful empirical studies, however, that measure the pervasiveness of the problem. Several studies have documented the relatively large share of income that certain subsets of the older population devote to health care (Crystal et al. 2000; Goldman and Zissimopoulos 2003; Maxwell, Moon, and Segal 2001), but we do not yet know how much these costs reduce living standards.

This study examines the impact of health problems at older ages on out-of-pocket health care spending and other types of expenditures. The effects might be minimal if older people are generally well-insured or have substantial financial resources. For example, wealthy older adults 
hit with high out-of-pocket health care costs could dip into their savings to cover medical bills without having to reduce their standard of living. Otherwise, the onset of serious health problems could force many people to divert large shares of their spending to health care and away from other goods and services. The analysis uses a unique data source that includes information on both consumption patterns and specific medical conditions, and estimates models of different types of household expenditures. We examine spending patterns separately for households that are ages 65 and older and those that are ages 51 to 64 . The impact of health problems on spending patterns may be especially strong for those in the younger age group, most of whom do not yet qualify for Medicare, because some of them are uninsured or underinsured.

The results suggest that high out-of-pocket health care spending does not generally force older Americans to reduce their living standards. However, low-income adults in their fifties and early sixties appear to curtail their nonhealth spending in response to high health care expenses when they develop multiple medical conditions. These findings suggest that Medicare and Medicaid generally protect older adults from high out-of-pocket health care costs, but that important gaps in the health care safety net exist for older people who have not yet reached the Medicare eligibility age of 65 .

\section{Background}

The onset of serious health problems generally increases the use of health services and medications, raising out-of-pocket medical expenses despite the preponderance of third-party payments. Hwang et al. (2001), for example, found that adults ages 45 to 64 with three or more chronic conditions averaged $\$ 1,055$ in annual out-of-pocket payments for health care services in 1996, compared with only $\$ 356$ for those with no chronic conditions. The same study reported 
similar spending patterns for adults ages 65 and older, nearly all of whom have Medicare coverage. Although out-of-pocket spending levels of about $\$ 1,000$ may not be catastrophic for most people, some older adults with chronic conditions face very high expenses. For example, about 1 in 10 Medicare beneficiaries ages 65 and older with acute myocardial infarction spend more than $\$ 3,500$ (in 1999 constant dollars) annually on out-of-pocket health care spending in the first year of diagnosis (Joyce et al. 2005).

The out-of-pocket cost implications of chronic health conditions are especially serious for older Americans, because the incidence of health problems increases rapidly with age. For example, 59 percent of adults ages 70 and older experience a major new medical condition (cancer, stroke, heart problems, lung disease, psychiatric problems, or diabetes) over about a 10year period or are married to someone who does (Johnson, Mermin, and Uccello 2006). The risks are nearly as high for people ages 51 to 61,57 percent of whom experience new health problems over a 10-year period. Most older Americans report at least one chronic condition, and nearly half of persons with chronic conditions have more than one (Hoffman, Rice, and Sung 1996). In 1996, the share of Americans with at least one chronic condition reached 58 percent at ages 45 to 64, 78 percent at ages 65 to 79, and 85 percent at ages 80 and older (Hwang et al. 2001). About 52 percent of adults ages 65 to 79 had two or more chronic conditions in 1996.

\section{Medicare Coverage}

Although nearly all Americans ages 65 and older are covered by Medicare, they face significant cost-sharing requirements. Copayments by Medicare beneficiaries rise with services use and can accumulate rapidly. After meeting the annual deductible, beneficiaries must pay 20 percent of the costs of Medicare Part B services out of pocket, which include doctor visits and 
many other outpatient services. The Part B deductible stands at \$135 in 2009 (Centers for Medicare and Medicaid Services [CMS] 2008b). Hospitalizations, which are covered by Medicare Part A, can be especially costly. Medicare beneficiaries face annual deductibles of $\$ 1,068$ for hospital stays in 2009 . There are no additional charges for the first 60 days, but daily copayments amount to \$267 for days 61 to 90 , and \$534 for days 91 to 150 . Longer hospital stays are not covered at all.

Until 2006, the lack of prescription drug coverage was by far the most important hole in the Medicare benefits package. In the mid-1990s, for example, drug costs accounted for between one-third and one-half of out-of-pocket spending on health care services by older Medicare beneficiaries (Crystal et al. 2000; Hwang et al. 2001), and rising prescription drug use and prices increased real out-of-pocket drug spending by Medicare beneficiaries by 61 percent between 1997 and 2001 (Moeller, Miller, and Banthin 2004).

The 2006 addition of Part D to Medicare provides a voluntary outpatient prescription drug benefit delivered by private insurance plans, but many Medicare beneficiaries continue to make substantial out-of-pocket payments for their prescription drugs. Although the Part D drug plans provide a range of coverage options at different prices, they must provide the standard benefit defined in law, its actuarial equivalent, or an enhanced benefit. The standard benefit has a \$295 deductible in 2009 and 25 percent coinsurance until total drug costs reach \$2,700 (CMS 2008a). Coverage is suspended after total drug costs exceed this level, and beneficiaries must pay 100 percent of their drug costs until total out-of-pocket spending reaches $\$ 4,350$. The plan then pays 95 percent of any additional costs, with beneficiaries responsible for only the remaining 5 percent. Although some plans cover beneficiaries in the standard coverage gap, only 4 percent of Part D enrollees had coverage in the gap for brand-name drugs in 2006 (Cubanski and Neuman 
2006). Medicare Part D appears to have raised use of essential medications for seniors and reduced out-of-pocket spending in 2006 (Schneeweiss et al. 2009), but patients reduced their medication usage when they entered the coverage gap (Zhang et al. 2009).

Medicare premiums are substantial. Although most beneficiaries do not pay Medicare Part A premiums for inpatient services, most now pay monthly premiums of $\$ 96.40$ for Medicare Part B, which covers outpatient services. Beginning in 2007, Part B premiums are somewhat higher for high-income enrollees (single adults with incomes over $\$ 85,000$ and couples with incomes over $\$ 170,000$ in 2009). Part D premiums vary depending on the particular plan that enrollees choose, but monthly premiums for the standard plan averaged \$27 per month in 2007 (Medicare Trustees 2007). Low-income beneficiaries qualify for public assistance with premiums, deductibles, and copays for both Parts B and D, but there is concern that many eligible enrollees are not receiving help (Kaiser Family Foundation 2007; Levy and Weir. 2007; Moon, Brennan, and Segal 1998).

Additionally, Medicare does not cover all health care services received by older adults. Excluded services include dental care and dentures, routine vision care and eyeglasses, and hearing examinations and hearing aids, as well as most long-term care services.

\section{Supplemental Coverage for Medicare Beneficiaries}

Many older Americans obtain private supplemental insurance to fill some of the gaps in Medicare coverage, defraying the cost of Medicare deductibles and coinsurance and covering services excluded from the Medicare benefits package. In 2005, about 36 percent of noninstitutionalized Medicare enrollees ages 65 and older obtained retiree health benefits from their former employers or their spouses' former employers, while another 35 percent purchased 
private supplemental coverage, known as Medigap, from insurance companies (Federal Interagency Forum on Aging Related Statistics 2008).

However, many employers are now cutting back on retiree health benefits, likely reducing employer coverage rates for future generations of Medicare beneficiaries. Between 1988 and 2006, the share of large private employers offering health benefits to retirees fell from 66 to 35 percent (Kaiser Family Foundation and Health Research and Educational Trust 2006). In 2003, only 25 percent of private-sector workers were employed at establishments that offered retiree health benefits, down from 32 percent in 1997 (Buchmueller, Johnson, and Lo Sasso 2006). Employers that continue to offer benefits are forcing retirees to bear much of the costs. From 1998 to 2004, the median amount that retirees ages 65 and older paid in premiums for employer-provided health insurance more than quadrupled, after adjusting for inflation (Johnson 2007). Nonetheless, employer health plans still provide important benefits to retirees fortunate enough to participate in them. In 2004, the median Medicare-enrolled retiree with employer health benefits paid less than half as much in premiums as the median Medigap enrollee (Johnson 2007).

Some older Americans who lack employer-sponsored retiree health benefits turn to the Medicare Advantage Program, which delivers traditional Medicare benefits to enrollees through private health plans. ${ }^{1}$ Enrollment in these plans has been soaring in recent years, partly because they often provide services not included in the traditional Medicare program and thus can lower enrollees' out-of-pocket costs. In 2008, about one in five Medicare beneficiaries were enrolled in a Medicare Advantage plan (Gold 2008). Older adults with very limited incomes and assets may qualify for Medicaid, which pays virtually all health care costs for enrollees. Eligibility rules

\footnotetext{
${ }^{1}$ Some employers offer retiree health benefits through Medicare Advantage plans. About 16 percent of Medicare Advantage enrollees in 2007 were in employer plans (Gold 2008).
} 
vary by state, but the average income cut-off across all states is about 88 percent of the federal poverty threshold. ${ }^{2}$ Most state programs also include medically needy provisions that grant Medicaid benefits to older adults with high out-of-pocket health care spending. Medicaid covered about 12 percent of all Medicare beneficiaries in 2005 (Federal Interagency Forum on Aging Related Statistics 2008), but many eligible older Americans fail to enroll in Medicaid. Take-up rates may be low because of the stigma associated with the receipt of means-tested benefits or because few eligible people are fully informed about the program (Moon, Brennan, and Segal 1998).

\section{Coverage Options at Younger Ages}

The impact of health problems on spending patterns may be greater for midlife adults than for those old enough to qualify for Medicare. More than 7 in 10 (71 percent) of adults ages 55 to 64 received employer-sponsored coverage in 2004, either as workers or retirees (Johnson 2007). Many of those without employer coverage, however, are uninsured or underinsured. About 12 percent of Americans ages 55 to 64 were uninsured in 2006, and another 8 percent purchased private nongroup coverage (Johnson 2007). Those without insurance can face catastrophic health care costs if they become ill, although many turn to charity care when they develop serious health problems (Johnson and Crystal 2000).

Relatively few nongroup policies provide comprehensive benefits. Because of the high cost of comprehensive coverage, many who purchase nongroup policies opt for plans that offer only limited coverage, with high deductibles, high cost-sharing requirements, and limited benefits. Policyholders with health problems sometimes opt for plans that exclude their pre-

\footnotetext{
${ }^{2}$ Authors' calculations from Kaiser Family Foundation (2004).
} 
existing conditions to keep premiums down. Moreover, insurers are often reluctant to offer lowdeductible comprehensive coverage because these policies generally attract people with health problems who use many services. This adverse selection problem drives up premiums and discourages all but the most heavy users of health services from purchasing coverage, causing the market for these policies to break down. Consequently, many people in their fifties and early sixties with nongroup coverage may be underinsured, leaving them vulnerable to high out-ofpocket costs if they become seriously ill. Even when older Americans below age 65 are able to afford the high cost of private nongroup coverage, they may be denied coverage by insurers.

How people respond to the onset of health problems and associated medical expenses likely depends on a number of factors, including age, financial status, insurance coverage, employment status, marital status, family networks, and the nature of the medical condition. Debilitating health problems that strike before retirement may force some people to drop out of the labor market prematurely, with serious repercussions on financial resources and spending. Health problems that strike at relatively young ages but are not disabling may induce others to delay retirement and remain at work until older ages, so that they can maintain their previous consumption levels of non-heath-related goods and services. In some families, the onset of serious health problems may lead the spouse to increase labor supply to maintain the couple's standard of living (Johnson and Favreault 2001). The ability to increase labor supply to offset the financial impact of rising medical costs diminishes with age, and those who become ill very late in life have little choice but to rely on insurance, savings, or current income to meet consumption needs. People with substantial incomes or assets may be able to cover their medical bills without reducing other spending, and those with comprehensive insurance coverage may not experience sharp increases in health care costs when they become ill. However, people of modest means 
without comprehensive insurance may be forced to cutback non-medical spending when they develop serious heath problems, or turn to family and friends (or the bankruptcy courts) for financial assistance.

Recent studies suggest that health care costs are quite burdensome for many older Americans, but the evidence is not conclusive. Research based on the Medicare Current Beneficiary Survey (MCBS) finds that older adults on average devote about one-fifth of their incomes to health care (Crystal et al. 2000; Federal Interagency Forum on Aging Related Statistics 2008; Gross et al. 1999; Maxwell, Moon, and Segal 2001). The share rises to about one-third for Medicare beneficiaries with limited incomes. However, the MCBS may overstate the financial burden of health care costs at older ages because survey respondents appear to understate their incomes (Goldman and Smith 2001). Estimates based on early 2000s data from the Medical Expenditure Panel Survey (MEPS) and the Health and Retirement Study (HRS) indicate that only about 12 percent of income went to health care spending for noninstitutionalized adults ages 65 and older (Federal Interagency Forum on Aging Related Statistics 2008; Johnson 2006). Nonetheless, 16 percent of adults ages 65 and older in the 2002 HRS devoted more than one-third of their household income to health care spending for themselves or their spouses (Johnson 2006). One limitation of these studies is that they do not account for the role that savings and extended family can play in cushioning the impact of high medical bills on economic well-being. Burdensome health care costs cannot persist indefinitely without affecting spending on other goods and services, but many families may be able to dip into their savings to maintain their living standards during relatively brief spells of expensive medical bills, or they may receive help from relatives. 


\section{Methods}

This study examines how the presence of particular medical conditions affects out-ofpocket health care spending and other types of household expenditures at older ages. We observe each household's annual spending on a wide range of goods and services up to three times (in 2001, 2003, and 2005), and estimate fixed effects models of household expenditure types as functions of medical conditions, income, wealth, and other characteristics. ${ }^{3}$

We examine several expenditure measures. In the health spending models, we consider two alternative dependent variables. In one specification, the dependent variable is the natural logarithm of total out-of-pocket health care costs (including spending on health insurance premiums, prescription drugs, health services, and medical supplies), and in the other it is the natural logarithm of out-of-pocket payments to providers. The second measure excludes health insurance premiums because they do not vary much with health status for most older people. Employers can not charge workers or retirees with health problems higher contributions than those without health problems, and Medigap premiums are not permitted to vary by the health status of the policyholder (except for people who delay purchasing Medigap after they qualify for Medicare). ${ }^{4}$ To measure effects of health problems on nonhealth spending, we first model the natural logarithm of total expenditures excluding all health care costs, and then the natural logarithm of total expenditures excluding all health care and housing costs. Housing costs are excluded in the alternative specification because it is unlikely that many people can reduce these expenses in the short term to offset rising health costs. We use the natural logarithm of

\footnotetext{
${ }^{3}$ The Hausman test indicates that fixed effects models are more appropriate for our data and specifications than random effects models.

${ }^{4}$ Older people in good health who do not expect to use many health services may choose to forego supplemental coverage, however, eliminating their premium payments.
} 
expenditures instead of the level to reduce skewness in the dependent variables. ${ }^{5}$ All expenditure variables are expressed in constant 2007 dollars (adjusted by the change in the consumer price index for all items) and divided by two for married couples to generate per capita measures.

We estimate the models at the household level and stratify the sample by age. We estimate separate models for households in which both spouses (if married) are ages 65 and older and for those in which both spouses are younger than 65 , because virtually every household in the older group has some Medicare coverage and some younger households may be uninsured or underinsured. In addition, a much larger share of the younger group than the older group works for pay. Both insurance coverage and employment status are likely to affect the impact of health problems on household expenditures.

The key predictors in our model are indicators for the presence of medical conditions. We tabulate the number of conditions that the respondent and spouse (if married) report from the following list: diabetes, high blood pressure, arthritis, heart problems, serious lung problems, psychiatric problems, cancer, and stroke. The total number of conditions is divided by two for married couples to generate a per capita measure. The models include an indicator variable identifying households with between two and three conditions per adult member (including those with 3.5 conditions) and another indicator identifying those with four or more conditions per adult member. We hypothesize that older adults with more medical conditions will spend more on health care than healthy older adults, and that they will spend less on other types of consumption. Because housing costs tend to be fixed in the short run, we expect that the impact of health problems may be greatest on non-housing spending. Alternatively, if most of the older

\footnotetext{
${ }^{5}$ We set the natural log equal to zero for households that do not spend anything on the expenditure category.
} 
population is well insured or has access to substantial savings or other financial resources, health problems may have little effect on consumption.

Other predictors in the models include the natural log of annual household income, the natural log of household financial assets, age (for both spouses if married), and an indicator for marital status. We do not include insurance coverage or employment status in the models because they are likely endogenous to spending decisions. All financial measures are expressed in constant 2007 dollars and divided by two for married couples.

We also estimate the models for a subsample of lower-income households, whose living standards may be especially likely to decline in the wake of high out-of-pocket health care spending. The per capita income threshold is set at $\$ 20,000$ for households younger than 65 , placing 28 percent of these households into the low-income group. For households ages 65 and older, we use a per capita income threshold of $\$ 15,000$, which leaves 33 percent of older households in the low-income group.

\section{Data}

Our data come from the Health and Retirement Study (HRS), a longitudinal survey of older Americans conducted by the Survey Research Center at the University of Michigan for the National Institute on Aging. Since 1992, HRS has been following several cohorts of older respondents and their spouses. In 2000, the survey interviewed a large, nationally representative sample of Americans ages 53 and older and their spouses, and re-interviewed them in 2002, 2004, and 2006. The HRS introduced a new cohort of respondents ages 51 to 56 in 2004 (born between 1948 and 1953) and their spouses, and reinterviewed them in 2006. The survey collects 
detailed information on a wide range of topics, including income, assets, health status, health insurance, and demographics.

HRS administered a supplemental mail survey on household expenditures to a subset of respondents in 2001, 2003, and 2005. This survey, the Consumption and Activities Mail Survey (CAMS), asked respondents to report household expenditures over the past 12 months on 32 different groups of goods and services designed to capture all household spending. With regard to health care costs, respondents reported premium payments for health insurance (including Medicare premiums), out-of-pocket spending on prescription and nonprescription medications, out-of-pocket spending on health services (including hospital care, doctor visits, lab tests, and eye, dental, and nursing home care), and out-of-pocket spending on medical supplies. With regard to housing, respondents reported payments for mortgages, rent, homeowners' and renters' insurance, electricity, water, heating fuel, home repair and maintenance, housekeeping and yard supplies, and telephone, cable, and Internet access. Data was collected for 3,866 households in 2001, 3,254 households in 2003, and 3,880 households in 2005. In combination with the information collected from the core HRS questionnaires, CAMS provides an unusually rich source of data on health status and expenditure patterns.

Our younger sample consists of 2,138 observations on households in which both spouses (if married) are under age 65 and at least one spouse is between the ages of 51 and 64 . The older sample consists of 2,393 observations on households in which both spouses (if married) are ages 65 and older. Except for the expenditure measures, all variables come from the core survey of the HRS. The income measures (which refer to the year preceding the HRS survey year) and the health measures (which refer to the two-year period preceding the HRS survey year) come from 
the HRS survey following the CAMS survey. All other variables come from the wave preceding the CAMS survey. ${ }^{6}$

\section{Results}

Table 1 shows the demographic, health, and economic characteristics of our two samples. The average age of CAMS respondents in our age 51 to 64 sample is about 56 and the average age in the 65 and older sample is about 75 . Households under age 65 are more likely to be married and uninsured than households ages 65 and older, and less likely to be non-Hispanic white. Younger households also tend to be more educated and report fewer medical conditions than older households.

Nearly all of the households in our samples include at least one adult with some kind of health insurance. About 7 percent of households under age 65 lack health insurance, compared with less than 1 percent of households ages 65 and older, nearly all of whom qualify for Medicare. Although few households are uninsured, many lack employer-provided health insurance, which is often more generous than nongroup coverage or Medicare. Nearly onequarter of households under age 65 and two-thirds of those ages 65 and older lack employerprovided health insurance, available to either workers or retirees.

Medical conditions are quite common at older ages. Less than one in four households ages 51 to 64 and 1 in 14 households ages 65 and older report fewer than one medical condition per adult member. More than two-fifths of households under age 65 and two-thirds of households ages 65 and older have two or more medical conditions per adult member. Arthritis

\footnotetext{
${ }^{6}$ For 2001 expenditures, for example, spending data come from the 2001 CAMS, income and health data come from the 2002 HRS core survey, and all other data come from the 2000 HRS core survey.
} 
and high blood pressure are the most common medical conditions, each afflicting about threefifths of households under age 65 and about three-quarters of households ages 65 and older.

Table 2 shows mean and median annual per capita out-of-pocket household health expenditures by age. On average, households with an adult ages 51 to 64 (and with a spouse younger than 65 if married) spend about $\$ 2,400$ per capita on health expenses, about 8 percent of their total spending. Older households spend more out of pocket on health care than households under age 65 in both absolute and relative terms. On average, households ages 65 and older spend about $\$ 3,000$ per capita on health care, 12 percent of their total spending. Insurance premiums account for more than two-fifths of out-of-pocket health care spending by older households. Per capita out-of-pocket payments to health care providers (which excludes insurance premiums) average about $\$ 1,300$ for the younger households in our sample and about $\$ 1,700$ for the older households. Total spending excluding health and housing expenses - the measure potentially most sensitive to out-of-pocket medical spending—averages $\$ 14,757$ per capita for households under age 65 and $\$ 11,546$ per capita for those ages 65 and older. Distributions for all types of spending are skewed towards high spenders, with mean values exceeding median values by substantial margins in all categories.

Table 3 reports median annual per capita health spending by the presence of specific medical conditions. Not surprisingly, out-of-pocket health care spending increases with the number of medical conditions. For example, households ages 65 and older with fewer than one medical condition per adult member report median per capita spending of $\$ 1,516$, compared with $\$ 2,054$ for those with 1 or 1.5 conditions, $\$ 2,400$ for those with 2 or 2.5 conditions, and about $\$ 2,600$ for those with four or more conditions. The relationship between out-of-pocket health care spending and medical conditions is even stronger when we exclude premium payments. 
Median out-of-pocket payments to health care providers are 2.6 times higher for households ages 65 and older with four or more medical conditions per adult member than for their counterparts with fewer than one medical condition per adult member.

Out-of-pocket spending on health care providers (which excludes insurance premiums) is especially high for older households with heart problems, diabetes, and stroke. For households with heart problems, for example, median out-of-pocket payments to health care providers reached $\$ 1,239$ per year at ages 65 and older, and $\$ 876$ at ages 51 to 64 . Health problems are associated with higher levels of out-of-pocket health care spending for all medical conditions we consider except for lung problems. These comparisons are complicated by correlations between medical conditions and demographics and income. For example, among households under age 65 , mean per capita income is about $\$ 17,000$ lower for households with lung problems than for those without and almost $\$ 25,000$ lower for households with three or more medical conditions than for households without medical conditions (not shown). To gauge the true impact of health problems on spending, it is important to estimate multivariate models that hold other factors constant.

\section{Model Estimates}

Tables 4 and 5 examine the impact of the number of per capita medical conditions on outof-pocket health and nonhealth spending, controlling for demographics, income, and wealth. The tables show coefficients from fixed effects models of the natural logarithm of per capita out-ofpocket health expenditures, out-of-pocket health expenditures excluding premiums, total expenditures excluding health-relating spending, and total expenditures excluding health and housing costs. 
Among all households with an adult ages 51 to 64 (and with a spouse younger than 65 if married), medical conditions substantially increase out-of-pocket health spending (table 4). The presence of two or three medical conditions per adult member of the household has no significant impact on total out-of-pocket health expenditures, but increases health expenditures exclusive of premiums by 63 percent $\left(\mathrm{e}^{0.49}-1\right)$. The presence of four or more conditions per capita increases total out-of-pocket health expenditures by 79 percent and out-of-pocket health expenditures exclusive of premiums by 206 percent. However, these models provide no evidence that increased spending crowds out nonhealth consumption for typical adults ages 51 to 64 . The coefficients on medical conditions in the nonhealth spending equations are small and insignificant (with t-statistics less than 1).

When we restrict the sample to low-income households (with annual per capita incomes below \$20,000), we find evidence that high out-of-pocket health care spending forces people with limited financial resources to lower their living standards. The presence of four or more medical conditions per capita increases out-of-pocket health spending exclusive of premiums by 310 percent relative to the presence of 1.5 or fewer medical conditions. (The standard error on the coefficient is more than twice as large in the restricted sample as in the full sample because the full sample includes many more observations. As a result, the estimated effect in the restricted sample is only marginally significant.) Medical conditions also significantly reduce nonhealth spending. The presence of two or three medical conditions per adult member of the household reduces total expenditures excluding health care by 26 percent for low-income households ages 51 to 64 and reduces total expenditures excluding health and housing costs by 30 percent. The presence of four or more medical conditions reduces total spending less health and housing costs by 35 percent. 
Medical conditions have smaller effects on health and nonhealth spending for households ages 65 and older, nearly all of whom have Medicare coverage and many of whom supplement Medicare with private insurance. The presence of two or three medical conditions per adult member of the household increases out-of-pocket health care spending exclusive of premiums by only 22 percent (relative to no more than 1.5 conditions per capita), and the effect is not quite significant $(p<0.101)$. Having four or more conditions increases out-of-pocket nonpremium health care spending by 32 percent, but again the impact is not statistically significant $(p<0.156)$. We find no significant effects of medical conditions on nonhealth spending. For older households with less than $\$ 15,000$ per year in per capita income, the presence of two or three medical conditions increases out-of-pocket health expenditures exclusive of premiums by 65 percent, and four or more conditions boosts nonpremium health expenditures by 172 percent. Again, however, we find no evidence that medical conditions reduce nonhealth spending.

\section{Conclusions}

Our findings suggest that high out-of-pocket health care spending does not generally force older Americans to reduce their living standards. While older adults with more medical conditions tend to spend more out of pocket on payments to health care providers than those with fewer conditions, they do not generally reduce their nonhealth spending significantly. For most older Americans, in fact, health care does not account for a large share of total spending. Median out-of-pocket spending on health care services, prescription drugs, medical supplies, and health insurance premiums totals only about $\$ 2,600$ per year among households ages 65 and older with four or more medical conditions. These represent the top sixth of households in terms of the number of health problems, yet their median health care spending accounts for only about 14 
percent of total median household spending. These relatively low levels of health care costs may explain why most older households do not need to cut back on other types of spending when they develop medical problems that increase health care expenses.

However, low-income adults ages 51 to 64 , who are too young to receive Medicare benefits unless they have disabilities, do appear to reduce nonhealth spending when they develop medical problems. After other factors are controlled for, adults in their fifties and early sixties with less than $\$ 20,000$ per year in per capita household income and two or three medical conditions spend 30 percent less on items other than health care and housing than their counterparts with fewer medical conditions. Those with four or more conditions spend 35 percent less than those with fewer than two conditions per adult member of the household.

Many observers have noted the apparent holes in the health care safety net for older people who have not yet reached age 65 and thus are not generally eligible for Medicare. Although expensive health problems become more common as people age, people in their fifties and early sixties can not rely on the federal government for health insurance coverage. Medicare eligibility does not begin until age 65, except for those with disabilities. Even the poorest older adults can not receive Medicaid benefits until age 65 unless they are disabled. Most rely on their employers (or their spouses' employers) for health benefits. However, some people in their fifties do not work, and some employers do not offer health benefits to their workers. Most workers with employer health benefits forfeit subsidized employer benefits when they leave their employers. They can usually receive unsubsidized continuation coverage if they separate before age 65 , but generally only for 18 months. Private nongroup insurance is typically quite expensive, especially for people with health problems, but it is often the only option for people without access to employer benefits seeking coverage. 
It is no surprise, then, that low-income people in their fifties and sixties would have to lower their living standards to cover their health expenses when they develop medical problems. Many are uninsured or underinsured, generally causing out-of-pocket health care costs to increase sharply when they develop chronic conditions. They typically lack the financial resources to maintain their consumption levels when medical costs surge, such as by dipping into their savings. Unlike many people ages 65 and older with adult children who are well-established in their careers, people in their fifties and sixties may lack family members who are able to provide financial help.

More surprising is our finding that health care spending does not crowd out other types of household spending for adults ages 65 and older, even among those with low incomes. Although virtually all Americans ages 65 and older receive Medicare benefits, the coverage gaps are well known. Beneficiaries usually face substantial cost-sharing requirements, including high deductibles and significant copays. Premiums for coverage of outpatient services are expensive. And several services are excluded from the basic Medicare package, most notably prescription drug coverage during the period covered by this study. Although Medicare began covering prescription drugs in 2006, coverage remains incomplete today (Schneeweiss et al. 2009). Many older adults supplement Medicare with private coverage from former employers or insurance companies, but premiums for supplemental coverage are expensive.

Our findings do not, however, necessarily imply that health problems pose no financial hardships for Americans ages 65 and older. Many older people may deplete their savings or go into debt to finance their health care while maintaining other types of spending. They may turn to family members to help with their medical bills, potentially creating financial difficulties for this wider social network. Or they may forego necessary medical care to keep their health costs 
down. More research is needed on the financial consequences of health problems at older ages to assess each of these possible outcomes.

\section{References}

Buchmueller, Thomas, Richard W. Johnson, and Anthony T. Lo Sasso. 2006. "Trends in Retiree Health Insurance, 1997-2003." Health Affairs 25(6): 1507-16.

Centers for Medicare and Medicaid Services (CMS). 2008a. "CMS Announces 2009 Medicare Advantage Payment Rates and MA Part D Payment Updates." http://www.cms.hhs.gov/apps/media/press/factsheet.asp?Counter=3034\&intNumPerPage $=10 \&$ checkDate $=\&$ checkKey $=\&$ srchType $=1 \&$ numDays $=3500 \&$ srchOpt $=0 \& \operatorname{srchData}=\&$ keywordType $=$ All $\&$ chkNewsType $=6 \&$ intPage $=\&$ showAll $=\& p Y e a r=\& y e a r=\& d e s c=$ false $\&$ cboOrder $=$ date.

— 2008b. "CMS Announces Medicare Premiums, Deductibles for 2009." http://www.cms.hhs.gov/apps/media/press/factsheet.asp?Counter=3272.

Crystal, Stephen, Richard W. Johnson, Jeffrey Harman, Usha Sambamoorthi, and Rizie Kumar. 2000. "Out-of-Pocket Health Care Costs Among Older Americans." Journal of Gerontology: Social Sciences 55B (1): S51-62.

Cubanski, Juliette, and Patricia Neuman. 2006. "Status Report on Medicare Part D Enrollment in 2006: Analysis of Plan-Specific Market Share and Coverage.” Health Affairs 26(2): W112.

Federal Interagency Forum on Aging Related Statistics. 2008. "Older Americans Update 2008: Key Indicators of Well-Being.” Washington, DC: U.S. Government Printing Office.

Gold, Marsha. 2008. "Medicare Advantage in 2008." Washington, D.C.: The Henry J. Kaiser Family Foundation.

Goldman, Dana P., and James P. Smith. 2001. "Methodological Biases in Estimating the Burden of Out-of-Pocket Expenses." Health Services Research 35(6): 1357-70.

Goldman, Dana P., and Julie M. Zissimopoulos. 2003. "High Out-of-Pocket Health Care Spending by the Elderly." Health Affairs 22(3): 194-202.

Gross, David J., Lisa Alecxih, Mary Jo Gibson, John Corea, Craig Caplan, and Normandy Brangan. 1999. "Out-of-Pocket Health Spending by Poor and Near-Poor Elderly Medicare Beneficiaries.” Health Services Research 34(1): 241-54. 
Hoffman, Catherine, Dorothy Rice, and Hai-Yen Sung. 1996. "Persons with Chronic Conditions: Their Prevalence and Costs." Journal of American Medical Association 276(18): 147379.

Hwang, Wenke, Wendy Weller, Henry Ireys, and Gerard Anderson. 2001. "Out-of-Pocket Medical Spending for Care of Chronic Conditions.” Health Affairs 20(6): 267-78.

Johnson, Richard W. 2006. "Health Insurance Coverage and Costs at Older Ages: Evidence from the Health and Retirement Study." AARP Public Policy Institute Report 2006-20. Washington, D.C.: AARP.

— 2007. "What Happens to Health Benefits After Retirement?" Work Opportunities for Older Americans Series 7. Chestnut Hill, MA: Center for Retirement Research at Boston College.

Johnson, Richard W., and Stephen Crystal. 2000. "Uninsured Status and Out-of-Pocket Costs at Midlife." Health Services Research 35 (5, Part I): 911-32.

Johnson, Richard W., and Melissa M. Favreault. 2001. "Retiring Together or Working Alone: The Impact of Spousal Employment and Disability on Retirement Decisions," CRR Working Paper No. 2001-01. Chestnut Hill, MA: Center for Retirement Research at Boston College.

Johnson, Richard W., Gordon B.T. Mermin, and Cori E. Uccello. 2006. "When the Nest Egg Cracks: Financial Consequences of Health Problems, Marital Status Changes, and Job Layoffs at Older Ages." Washington, D.C.: The Urban Institute.

Joyce, Geoffrey F., Emmett B. Keeler, Baoping Shang, and Dana P. Goldman. 2005. "The Lifetime Burden of Chronic Disease Among the Elderly.” Health Affairs Web Exclusive W5: R18-29.

Kaiser Family Foundation. 2004. "State Health Facts Online." http://statehealthfacts.kff.org.

—. 2007. "Low-Income Assistance Under the Medicare Drug Benefit." Menlo Park, CA: Kaiser Family Foundation.

Kaiser Family Foundation and Health Research and Educational Trust. 2006. Employer Health Benefits: Annual Survey. http://www.kff.org/insurance/ehbs-archives.cfm.

Levy, Helen, and David R. Weir. 2007. "Take-Up of Medicare Part D and the SSA Subsidy: Early Results from the Health and Retirement Study." Michigan Retirement Research Center Working Paper 2007-163. Ann Arbor, MI: University of Michigan.

Maxwell, Stephanie, Marilyn Moon, and Misha Segal. 2001. "Growth in Medicare and Out-ofPocket Spending: Impact on Vulnerable Beneficiaries." New York: Commonwealth Fund. 
Medicare Trustees. 2007. "2007 Annual Report of the Boards of Trustees of the Federal Hospital Insurance and Federal Supplementary Medical Insurance Trust Funds." Washington, DC: Medicare Trustees.

Moeller, John F., G. Edward Miller, and Jessica S. Banthin. 2004. "Looking Inside the Nation's Medicine Cabinet: Trends in Outpatient Drug Spending by Medicare Beneficiaries, 1997 and 2001." Health Affairs 23(5): 217-25.

Moon, Marilyn, Niall Brennan, and Misha Segal. 1998. "Options for Aiding Low-Income Medicare Beneficiaries.” Inquiry 35(3): 346-56.

Schneeweiss, Sebastian, Amanda R. Patrick, Alex Pedan, Laleh Varasteh, Raisa Levin, Nan Liu, and William H. Shrank. 2009. "The Effect of Medicare Part D Coverage on Drug Use and Cost Sharing Among Seniors Without Prior Drug Benefits." Health Affairs 28(2): W305-16.

Zhang, Yuting, Julie Marie Donohue, Joseph P. Newhouse, and Judith R. Lave. 2009. "The Effects of the Coverage Gap on Drug Spending: A Closer Look at Medicare Part D." Health Affairs 28(2): W317-25. 
Table 1. Sample Characteristics, by Age

\begin{tabular}{|c|c|c|}
\hline & 51 to 64 & 65 and Older \\
\hline & \multicolumn{2}{|c|}{ Mean } \\
\hline Respondent Age & 56.2 & 74.5 \\
\hline \multirow[t]{2}{*}{ Spouse Age } & 55.3 & 73.3 \\
\hline & \multicolumn{2}{|c|}{ Share with Characteristic (\%) } \\
\hline \multicolumn{3}{|l|}{ Marital Status } \\
\hline Married & 61.0 & 41.2 \\
\hline Unmarried & 39.0 & 58.8 \\
\hline \multicolumn{3}{|l|}{ Education } \\
\hline Not High School Graduate & 12.7 & 22.6 \\
\hline High School Graduate & 34.7 & 39.2 \\
\hline Some College & 26.7 & 21.1 \\
\hline College Graduate & 25.8 & 17.0 \\
\hline \multicolumn{3}{|l|}{ Race and Ethnicity } \\
\hline Non-Hispanic White, Other & 83.9 & 91.2 \\
\hline Non-Hispanic Black & 9.3 & 5.7 \\
\hline Hispanic & 6.8 & 3.1 \\
\hline \multicolumn{3}{|l|}{ Household Health Insurance } \\
\hline Employer & 76.0 & 37.0 \\
\hline Private Nongroup & 12.5 & 35.4 \\
\hline Public & 17.7 & 98.3 \\
\hline Uninsured & 7.3 & 0.3 \\
\hline \multicolumn{3}{|l|}{ Household Medical Conditions } \\
\hline Arthritis & 62.9 & 78.8 \\
\hline Cancer & 14.5 & 25.9 \\
\hline Diabetes & 21.0 & 21.7 \\
\hline Heart Problems & 21.6 & 40.2 \\
\hline High Blood Pressure & 59.2 & 69.2 \\
\hline Lung & 12.6 & 15.6 \\
\hline Psychological Problems & 26.3 & 16.3 \\
\hline Stroke & 5.9 & 11.6 \\
\hline \multicolumn{3}{|l|}{ No. of Per Capita Conditions } \\
\hline 0 or 0.5 & 22.8 & 6.8 \\
\hline 1 or 1.5 & 35.3 & 24.3 \\
\hline 2 or 2.5 & 23.3 & 31.5 \\
\hline 3 or 3.5 & 11.2 & 21.9 \\
\hline 4 or more & 7.4 & 15.4 \\
\hline \multirow[t]{2}{*}{2 to 3.5} & 34.5 & 53.4 \\
\hline & \multicolumn{2}{|c|}{ Median (2007 Dollars) } \\
\hline Per Capita Income & $\$ 33,912$ & $\$ 19,751$ \\
\hline Per Capita Financial Assets & $\$ 6,584$ & $\$ 22,387$ \\
\hline $\mathbf{N}$ & 3,714 & 4,806 \\
\hline
\end{tabular}

Source: Authors' estimates from Health and Retirement Study and Consumption Activities Mail Survey (CAMS).

Notes: Estimates are based on a pooled sample of CAMS respondents (one per household) from the 2001, 2003, and 2005 surveys. Age, education, and race refer to the CAMS respondent. The health insurance and medical condition measures indicate whether either the CAMS respondent or spouse has the specified insurance or condition. Public insurance refers to Medicare, Medicaid, Champus or Veterans Health Administration coverage. The younger sample excludes hous eholds with spouses ages 65 and older, and the older sample excludes households with spouses younger than 65 . 
Table 2. Per Capita Household Expenditures (2007 Dollars)

\begin{tabular}{|c|c|c|c|c|}
\hline & Health & $\begin{array}{l}\text { Health } \\
\text { Excluding } \\
\text { Premiums } \\
\end{array}$ & $\begin{array}{c}\text { All Spending } \\
\text { Except } \\
\text { Health } \\
\end{array}$ & $\begin{array}{c}\text { All Spending } \\
\text { Except } \\
\text { Health \& } \\
\text { Housing } \\
\end{array}$ \\
\hline \multicolumn{5}{|c|}{ Ages 51 to 64} \\
\hline Mean & 2,416 & 1,344 & 27,393 & 14,757 \\
\hline Median & 1,580 & 744 & 22,709 & 11,891 \\
\hline \multicolumn{5}{|c|}{ Ages 65 and Older } \\
\hline Mean & 3,004 & 1,721 & 21,328 & 11,546 \\
\hline Median & 2,298 & 983 & 16,293 & 8,492 \\
\hline
\end{tabular}

Source: Authors' estimates from Health and Retirement Study and Consumption Activities Mail Survey (CAMS).

Note: Estimates are based on a pooled sample of CAMS respondents (one per household) ages 51 to 64 and ages 65 and older and their spouses from the 2001, 2003 , and 2005 surveys. There are 3,714 observations in the younger sample and 4,806 observations in the older sample. The younger sample excludes households with spouses ages 65 and older, and the older sample excludes households with spouses younger than 65 . 
Table 3. Median Per Capita Household Health Expenditures by Presence of Medical Conditions, by Age (2007 Dollars)

\begin{tabular}{|c|c|c|c|c|}
\hline & & & 65 & der \\
\hline & $\begin{array}{c}\text { All } \\
\text { Health }\end{array}$ & $\begin{array}{c}\text { Health } \\
\text { Excluding } \\
\text { Premiums } \\
\end{array}$ & $\begin{array}{c}\text { All } \\
\text { Health }\end{array}$ & $\begin{array}{c}\text { Health } \\
\text { Excluding } \\
\text { Premiums } \\
\end{array}$ \\
\hline All & 1,580 & 744 & 2,298 & 983 \\
\hline Arthritis & & & & \\
\hline No & 1,518 & 663 & 2,128 & 849 \\
\hline Yes & 1,601 & 785 & 2,353 & 1,028 \\
\hline Cancer & & & & \\
\hline No & 1,539 & 716 & 2,206 & 955 \\
\hline Yes & 1,915 & 849 & 2,501 & 1,061 \\
\hline Diabetes & & & & \\
\hline No & 1,560 & 702 & 2,260 & 927 \\
\hline Yes & 1,707 & 913 & 2,444 & 1,171 \\
\hline Heart Problen & & & & \\
\hline No & 1,555 & 704 & 2,152 & 853 \\
\hline Yes & 1,746 & 876 & 2,548 & 1,239 \\
\hline High Blood P & & & & \\
\hline No & 1,368 & 637 & 2,107 & 819 \\
\hline Yes & 1,686 & 796 & 2,388 & 1,059 \\
\hline Lung & & & & \\
\hline No & 1,592 & 732 & 2,307 & 983 \\
\hline Yes & 1,538 & 822 & 2,271 & 985 \\
\hline Psychologica & & & & \\
\hline No & 1,577 & 710 & 2,288 & 969 \\
\hline Yes & 1,592 & 843 & 2,379 & 1,059 \\
\hline Stroke & & & & \\
\hline No & 1,577 & 737 & 2,288 & 966 \\
\hline Yes & 1,803 & 946 & 2,377 & 1,156 \\
\hline No. of Per Ca & & & & \\
\hline 0 or 0.5 & 1,242 & 527 & 1,516 & 468 \\
\hline 1 or 1.5 & 1,604 & 732 & 2,054 & 796 \\
\hline 2 or 2.5 & 1,592 & 849 & 2,400 & 1,063 \\
\hline 3 or 3.5 & 1,756 & 913 & 2,547 & 1,203 \\
\hline 4 or more & 1,721 & 1,007 & 2,599 & 1,239 \\
\hline 2 to 3.5 & 1,645 & 860 & 2,445 & 1,126 \\
\hline
\end{tabular}

Source: Authors' estimates from Health and Retirement Study and Consumption Activities Mail Survey (CAMS).

Notes: Estimates are based on a pooled sample of CAMS respondents (one per household) ages 51 to 64 and ages 65 and older and their spouses from the 2001, 2003, and 2005 surveys. There are 3,714 observations in the younger sample and 4,806 observations in the older sample. The younger sample excludes households with spouses ages 65 and older, and the older sample excludes households with spouses younger than 65 . 
Table 4. Coefficients from Fixed Effects Models of Per Capita Log Expenditures for Households Ages 51 to 64 (with Standard Errors in Parentheses and Marginal Effects in Brackets)

\begin{tabular}{|c|c|c|c|c|c|c|c|c|}
\hline & \multicolumn{4}{|c|}{ Total Sample } & \multicolumn{4}{|c|}{ Low-Income Sam ple } \\
\hline & $\begin{array}{c}\text { Health } \\
\text { Spending }\end{array}$ & $\begin{array}{l}\text { Health } \\
\text { Spending } \\
\text { Excluding } \\
\text { Premiums } \\
\end{array}$ & $\begin{array}{l}\text { All Spending } \\
\text { Except Health }\end{array}$ & $\begin{array}{c}\text { All Spending } \\
\text { Except Health \& } \\
\text { Housing } \\
\end{array}$ & $\begin{array}{c}\text { Health } \\
\text { Spending }\end{array}$ & $\begin{array}{c}\text { Health } \\
\text { Spending } \\
\text { Excluding } \\
\text { Premiums }\end{array}$ & $\begin{array}{l}\text { All Spending } \\
\text { Except Health }\end{array}$ & $\begin{array}{c}\text { All Spending } \\
\text { Except Health \& } \\
\text { Housing }\end{array}$ \\
\hline \multicolumn{9}{|c|}{ No. of Per Capita Conditions } \\
\hline 2 to 3.5 & $\begin{array}{r}0.19 \\
(0.16) \\
{[21 \%]}\end{array}$ & $\begin{array}{l}0.49^{* * *} \\
(0.17) \\
{[63 \%]}\end{array}$ & $\begin{array}{l}-0.01 \\
(0.05) \\
{[-1 \%]}\end{array}$ & $\begin{array}{l}-0.01 \\
(0.06) \\
{[-1 \%]}\end{array}$ & $\begin{array}{r}0.11 \\
(0.58) \\
{[12 \%]}\end{array}$ & $\begin{array}{r}0.62 \\
(0.59) \\
{[86 \%]}\end{array}$ & $\begin{array}{l}-0.30 * * \\
(0.15) \\
{[-26 \%]}\end{array}$ & $\begin{array}{c}-0.34 \text { * } \\
(0.18) \\
{[-30 \%]}\end{array}$ \\
\hline 4 or more & $\begin{array}{c}0.58 \text { * } \\
(0.31) \\
{[79 \%]}\end{array}$ & $\begin{array}{l}1.122^{* * *} \\
(0.33) \\
{[206 \%]}\end{array}$ & $\begin{array}{r}0.06 \\
(0.09) \\
{[6 \%]}\end{array}$ & $\begin{array}{r}-0.02 \\
(0.11) \\
{[-3 \%]}\end{array}$ & $\begin{array}{r}0.20 \\
(0.80) \\
{[21 \%]}\end{array}$ & $\begin{array}{r}1.41 \text { * } \\
(0.81) \\
{[310 \%]}\end{array}$ & $\begin{array}{r}-0.26 \\
(0.20) \\
{[-23 \%]}\end{array}$ & $\begin{array}{c}-0.42 \text { * } \\
(0.25) \\
{[-35 \%]}\end{array}$ \\
\hline \multicolumn{9}{|l|}{ Age } \\
\hline Respondent Age & $\begin{array}{l}0.06 \text { ** } \\
(0.02)\end{array}$ & $\begin{array}{l}0.08^{* * *} \\
(0.03)\end{array}$ & $\begin{array}{l}-0.022^{* * *} \\
(0.01)\end{array}$ & $\begin{array}{l}-0.04 \text { *** } \\
(0.01)\end{array}$ & $\begin{array}{r}0.06 \\
(0.07)\end{array}$ & $\begin{array}{l}0.13 \\
(0.07)\end{array}$ & $\begin{array}{r}-0.02 \\
(0.02)\end{array}$ & $\begin{array}{l}-0.07^{* * *} \\
(0.02)\end{array}$ \\
\hline Spouse Age & $\begin{array}{l}-0.03 \\
(0.03)\end{array}$ & $\begin{array}{l}-0.07^{\text {***}} \\
(0.03)\end{array}$ & $\begin{array}{r}0.01 \\
(0.01)\end{array}$ & $\begin{array}{r}0.01 \\
(0.01)\end{array}$ & $\begin{array}{l}-0.16 \text { * } \\
(0.09)\end{array}$ & $\begin{array}{l}-0.21 \text { ** } \\
(0.09)\end{array}$ & $\begin{array}{l}-0.06 \text { ** } \\
(0.02)\end{array}$ & $\begin{array}{r}-0.05 \\
(0.03)\end{array}$ \\
\hline Married & $\begin{array}{r}1.73 \\
(1.47)\end{array}$ & $\begin{array}{l}4.05^{* \star *} \\
(1.56)\end{array}$ & $\begin{array}{l}-1.24 \text { *** } \\
(0.44)\end{array}$ & $\begin{array}{l}-0.84 \text { * } \\
(0.51)\end{array}$ & $\begin{array}{l}10.28^{* *} \\
(5.25)\end{array}$ & $\begin{array}{l}12.90 \text { ** } \\
(5.35)\end{array}$ & $\begin{array}{l}2.78 \text { ** } \\
(1.33)\end{array}$ & $\begin{array}{r}2.21 \\
(1.63)\end{array}$ \\
\hline Log Income & $\begin{array}{r}-0.04 \\
(0.04)\end{array}$ & $\begin{array}{r}-0.02 \\
(0.04)\end{array}$ & $\begin{array}{l}-0.03 \text { ** } \\
(0.01)\end{array}$ & $\begin{array}{r}-0.02 \\
(0.01)\end{array}$ & $\begin{array}{r}-0.03 \\
(0.08)\end{array}$ & $\begin{array}{r}-0.02 \\
(0.08)\end{array}$ & $\begin{array}{l}-0.05^{* * *} \\
(0.02)\end{array}$ & $\begin{array}{r}-0.03 \\
(0.02)\end{array}$ \\
\hline Log Assets & $\begin{array}{l}0.03^{* * *} \\
(0.01)\end{array}$ & $\begin{array}{r}0.02 \\
(0.01)\end{array}$ & $\begin{array}{l}0.0005 \\
(0.004)\end{array}$ & $\begin{array}{l}-0.001 \\
(0.004)\end{array}$ & $\begin{array}{r}0.02 \\
(0.04)\end{array}$ & $\begin{array}{l}0.005 \\
(0.04)\end{array}$ & $\begin{array}{l}0.004 \\
(0.01)\end{array}$ & $\begin{array}{r}-0.01 \\
(0.01)\end{array}$ \\
\hline Intercept & $\begin{array}{l}3.70 \text { ** } \\
(1.44)\end{array}$ & $\begin{array}{r}1.11 \\
(1.53)\end{array}$ & $\begin{array}{l}12.06^{* * *} \\
(0.43)\end{array}$ & $\begin{array}{l}11.93^{* * *} \\
(0.50)\end{array}$ & $\begin{array}{r}2.50 \\
(4.12)\end{array}$ & $\begin{array}{r}-2.84 \\
(4.19)\end{array}$ & $\begin{array}{l}11.85^{* * *} \\
(1.04)\end{array}$ & $\begin{array}{l}13.41^{* * *} \\
(1.28)\end{array}$ \\
\hline F Statistic & 3.06 & 4.51 & 14.99 & 9.41 & 0.75 & 1.42 & 5.66 & 5.16 \\
\hline R2 Within & 0.014 & 0.020 & 0.063 & 0.040 & 0.015 & 0.029 & 0.105 & 0.097 \\
\hline R2 Between & 0.006 & 0.004 & 0.001 & 0.002 & 0.002 & 0.002 & 0.002 & 0.005 \\
\hline R2 Overall & 0.004 & 0.003 & 0.002 & 0.001 & 0.004 & 0.002 & 0.007 & 0.0001 \\
\hline No. of Observations & 3,714 & 3,714 & 3,714 & 3,714 & 1,152 & 1,152 & 1,152 & 1,152 \\
\hline No. of Households & 2,138 & 2,138 & 2,138 & 2,138 & 808 & 808 & 808 & 808 \\
\hline
\end{tabular}

Source: Authors' estimates from Health and Retirement Study and Consumption Activities Mail Survey (CAMS).

Notes: Estimates are based on a pooled sample of CAMS respondents (one per household) from the 2001, 2003, and 2005 surveys. Households with spouses ages 65 and older are excluded. The low-income sample consists of respondents with no more than $\$ 20,000$ in per capita annual income. The unit of observation is the person-year.

${ }^{*} \mathrm{p}<.10 ; \quad{ }^{* *} \mathrm{p}<.05 ; * * * \mathrm{p}<.01$ 
Table 5. Coefficients from Fixed Effects Models of Per Capita Log Expenditures for Households Ages 65 and Older (with Standard Errors in Parentheses and Marginal Effects in Brackets)

\begin{tabular}{|c|c|c|c|c|c|c|c|c|}
\hline & \multicolumn{4}{|c|}{ Total Sample } & \multicolumn{4}{|c|}{ Low-Income Sample } \\
\hline & $\begin{array}{c}\text { Health } \\
\text { Spending }\end{array}$ & $\begin{array}{c}\text { Health } \\
\text { Spending } \\
\text { Excluding } \\
\end{array}$ & $\begin{array}{l}\text { All Spending } \\
\text { Except Health }\end{array}$ & $\begin{array}{c}\text { All Spending } \\
\text { Except Health \& } \\
\text { Housing } \\
\end{array}$ & $\begin{array}{c}\text { Health } \\
\text { Spending }\end{array}$ & $\begin{array}{l}\text { Health } \\
\text { Spending } \\
\text { Excluding }\end{array}$ & $\begin{array}{l}\text { All Spending } \\
\text { Except Health }\end{array}$ & $\begin{array}{c}\text { All Spending } \\
\text { Except Health \& } \\
\text { Housing }\end{array}$ \\
\hline \multicolumn{9}{|c|}{ No. of Per Capita Conditions } \\
\hline 2 to 3.5 & $\begin{array}{r}0.06 \\
(0.10) \\
{[5 \%]}\end{array}$ & $\begin{array}{r}0.20 \\
(0.12) \\
{[22 \%]}\end{array}$ & $\begin{array}{r}0.04 \\
(0.04) \\
{[3 \%]}\end{array}$ & $\begin{array}{r}0.05 \\
(0.05) \\
{[5 \%]}\end{array}$ & $\begin{array}{r}0.08 \\
(0.26) \\
{[8 \%]}\end{array}$ & $\begin{array}{l}0.51 \text { * } \\
(0.29) \\
{[65 \%]}\end{array}$ & $\begin{array}{r}0.10 \\
(0.09) \\
{[11 \%]}\end{array}$ & $\begin{array}{r}0.13 \\
(0.10) \\
{[14 \%]}\end{array}$ \\
\hline 4 or more & $\begin{array}{r}0.18 \\
(0.16) \\
{[19 \%]}\end{array}$ & $\begin{array}{r}0.28 \\
(0.20) \\
{[32 \%]}\end{array}$ & $\begin{array}{r}0.002 \\
(0.07) \\
{[0 \%]}\end{array}$ & $\begin{array}{r}0.04 \\
(0.08) \\
{[4 \%]}\end{array}$ & $\begin{array}{c}0.70 \text { * } \\
(0.41) \\
{[101 \%]}\end{array}$ & $\begin{array}{l}1.00 \text { ** } \\
(0.46) \\
{[172 \%]}\end{array}$ & $\begin{array}{r}0.21 \\
(0.14) \\
{[23 \%]}\end{array}$ & $\begin{array}{r}0.19 \\
(0.16) \\
{[20 \%]}\end{array}$ \\
\hline \multicolumn{9}{|l|}{ Age } \\
\hline Respondent Age & $\begin{array}{l}-0.03 \text { ** } \\
(0.01)\end{array}$ & $\begin{array}{r}0.01 \\
(0.02)\end{array}$ & $\begin{array}{l}-0.04^{* * *} \\
(0.01)\end{array}$ & $\begin{array}{l}-0.07^{* * *} \\
(0.01)\end{array}$ & $\begin{array}{l}-0.04 \\
(0.04)\end{array}$ & $\begin{array}{l}-0.03 \\
(0.04)\end{array}$ & $\begin{array}{l}-0.06 \text { *** } \\
(0.01)\end{array}$ & $\begin{array}{l}-0.10^{* * *} \\
(0.01)\end{array}$ \\
\hline Spouse Age & $\begin{array}{r}0.02 \\
(0.02)\end{array}$ & $\begin{array}{l}0.002 \\
(0.02)\end{array}$ & $\begin{array}{r}0.01 \\
(0.01)\end{array}$ & $\begin{array}{l}0.02^{\text {***}} \\
(0.01)\end{array}$ & $\begin{array}{r}0.02 \\
(0.04)\end{array}$ & $\begin{array}{r}0.01 \\
(0.05)\end{array}$ & $\begin{array}{l}0.004 \\
(0.01)\end{array}$ & $\begin{array}{r}0.02 \\
(0.02)\end{array}$ \\
\hline Married & $\begin{array}{l}-1.63 \\
(1.33)\end{array}$ & $\begin{array}{r}-0.24 \\
(1.66)\end{array}$ & $\begin{array}{l}-1.05 \text { * } \\
(0.56)\end{array}$ & $\begin{array}{l}-2.27^{* * *} \\
(0.63)\end{array}$ & $\begin{array}{l}-2.16 \\
(3.58)\end{array}$ & $\begin{array}{l}-1.00 \\
(3.98)\end{array}$ & $\begin{array}{r}-1.19 \\
(1.18)\end{array}$ & $\begin{array}{l}-2.37^{*} \\
(1.39)\end{array}$ \\
\hline Log Income & $\begin{array}{r}0.02 \\
(0.05)\end{array}$ & $\begin{array}{r}0.09 \\
(0.06)\end{array}$ & $\begin{array}{r}0.03 \\
(0.02)\end{array}$ & $\begin{array}{r}0.03 \\
(0.02)\end{array}$ & $\begin{array}{r}0.04 \\
(0.16)\end{array}$ & $\begin{array}{l}0.52 \text { *** } \\
(0.18)\end{array}$ & $\begin{array}{r}0.02 \\
(0.05)\end{array}$ & $\begin{array}{l}-0.02 \\
(0.06)\end{array}$ \\
\hline Log Assets & $\begin{array}{l}-0.001 \\
(0.01)\end{array}$ & $\begin{array}{l}0.004 \\
(0.01)\end{array}$ & $\begin{array}{r}-0.004 \\
(0.00)\end{array}$ & $\begin{array}{l}0.002 \\
(0.00)\end{array}$ & $\begin{array}{l}-0.03 \\
(0.02)\end{array}$ & $\begin{array}{r}-0.02 \\
(0.03)\end{array}$ & $\begin{array}{l}0.002 \\
(0.01)\end{array}$ & $\begin{array}{r}0.01 \\
(0.01)\end{array}$ \\
\hline Intercept & $\begin{array}{l}9.30^{* * *} \\
(1.18)\end{array}$ & $\begin{array}{l}4.98^{* * *} \\
(1.48)\end{array}$ & $\begin{array}{l}12.40^{* * *} \\
(0.49)\end{array}$ & $\begin{array}{l}14.49^{\text {*** }} \\
(0.56)\end{array}$ & $\begin{array}{l}9.50 \text { *** } \\
(3.15)\end{array}$ & $\begin{array}{r}3.06 \\
(3.49)\end{array}$ & $\begin{array}{l}13.62^{* * *} \\
(1.04)\end{array}$ & $\begin{array}{l}16.40^{* * *} \\
(1.22)\end{array}$ \\
\hline F Statistic & 0.76 & 0.92 & 15.54 & 24.39 & 1.06 & 2.11 & 6.39 & 9.50 \\
\hline R2 Within & 0.002 & 0.003 & 0.043 & 0.066 & 0.012 & 0.024 & 0.069 & 0.099 \\
\hline R2 Between & 0.010 & 0.039 & 0.034 & 0.016 & 0.041 & 0.001 & 0.025 & 0.004 \\
\hline R2 Overall & 0.004 & 0.029 & 0.035 & 0.020 & 0.025 & 0.003 & 0.030 & 0.011 \\
\hline No. of Observations & 4,806 & 4,806 & 4,806 & 4,806 & 1,648 & 1,648 & 1,648 & 1,648 \\
\hline No. of Households & 2,393 & 2,393 & 2,393 & 2,393 & 1,036 & 1,036 & 1,036 & 1,036 \\
\hline
\end{tabular}

Source: Authors' estimates from Health and Retirement Study and Consumption Activities Mail Survey (CAMS).

Notes: Estimates are based on a pooled sample of CAMS respondents (one per household) from the 2001, 2003, and 2005 surveys. Households with spouses younger than 65 are excluded. The low-income sample consists of respondents with no more than $\$ 15,000$ in per capita annual income. The unit of observation is the person-year.

${ }^{*} \mathrm{p}<.10 ; \quad{ }^{* *} \mathrm{p}<.05 ; \quad{ }^{* *} \mathrm{p}<.01$ 


\section{RECENT WORKING PAPERS FROM THE}

\section{CENTER FOR RETIREMENT RESEARCH AT BOSTON COLLEGE}

Financial Hardship Before and After Social Security's Early Eligibility Age Richard W. Johnson and Gordon B.T. Mermin, March 2009

Rising Tides and Retirement: The Aggregate and Distributional Effects of Differential Wage Growth on Social Security

Melissa M. Favreault, March 2009

Accounting for the Heterogeneity in Retirement Wealth

Fang Yang, January 2009

Labor Supply Elasticity and Social Security Reform

Selahattin Imrohorolu and Sagiri Kitao, January 2009

Evaluating Micro-Survey Estimates of Wealth and Saving

Barry P. Bosworth and Rosanna Smart, January 2009

Portfolio Choice in Retirement: Health Risk and the Demand for Annuities, Housing, and Risky Assets

Motohiro Yogo, January 2009

The Disappearing Defined Benefit Pension and its Potential Impact on the Retirement Incomes of Boomers

Barbara A. Butrica, Howard M. Iams, Karen E. Smith, and Eric J. Toder, January 2009

Retirement and Social Security: A Time Series Approach

Brendan Cushing-Daniels and C. Eugene Steuerle, January 2009

Economic Restructuring and Retirement in Urban China

John Giles, January 2009

Sources of Support for Pension Reform: A Cross-National Perspective

Michelle Dion and Andrew Roberts, January 2009

The Long-Term Effect of the Divorce Revolution: Health, Wealth, and Labor Supply

Kristin Mammen, December 2008

All working papers are available on the Center for Retirement Research website

(http://www.bc.edu/crr) and can be requested by e-mail (crr@bc.edu) or phone (617-552-1762). 